\title{
ABORDAGENS TEÓRICAS SOBRE O ASSOCIATIVISMO E SEUS EFEITOS DEMOCRÁTICOS*
}

\section{Lígia Helena Hahn Lüchmann}

\section{Introdução}

As condições e os impactos das associações na vida social podem ser analisados de diversas maneiras e seguindo variados objetivos e enfoques analíticos, a fim de avaliar: as influências dos grupos e associações no processo de socialização dos indiví-

* Agradeço a Mark Warren (UBC) e aos integrantes do Núcleo de Pesquisa em Movimentos Sociais da Universidade Federal de Santa Catarina (NPMS-UFSC), em especial a Ilse Scherer-Warren, Julian Borba e Domitila Costa Cayres, pela leitura e comentários. Agradeço também às críticas, aos comentários e às sugestôes feitas pelos pareceristas anônimos da revista, embora nem todas tenham sido devidamente incorporadas ao artigo. Esta é uma versão revisada do trabalho apresentado no XV Congresso Brasileiro de Sociologia (SBS, 2011), fruto da pesquisa de bolsa de produtividade do CNPq.

Artigo recebido em 22/03/2012

Aprovado em 26/02/2014 duos; as potencialidades em promover a reprodução, a integração ou a transformação social; suas capacidades de alavancar o desenvolvimento econômico; o fomento de estruturas de pertencimento e de identidade cultural, entre outros. Inserido no campo da sociologia política, este trabalho observará as relações entre as associações e a democracia tendo como cenário as sociedades contemporâneas marcadas por alto grau de complexidade e de pluralidade da vida social.

$\mathrm{O}$ interesse por esse tema segue uma importante tendência teórica que tem renovado ou revivido, em boa parte a partir de Tocqueville, as análises da importância das associaçôes para a democracia, cuidando para diferenciar tanto as potencialidades democráticas das associações quanto as variadas concepçôes de democracia que as sustentam. Em seu livro Democracy and association (2001), Mark Warren aponta para a emergência de um consenso no interior da teoria democrática acerca da importância 
da vida associativa para a democracia, pelo fato de as associaçōes serem reconhecidas por seu cultivo ao desenvolvimento de virtudes cívicas, consideradas cruciais para uma sociedade democrática. Além disso, e entre outras contribuiçōes, as associaçōes permitiriam ampliar os domínios das práticas democráticas para diversas esferas da vida social, constituindo meios alternativos para dar voz aos desfavorecidos em função das condições desiguais de distribuição de dinheiro e poder (cf. Warren, 2001; Fung, 2003; Cohen, 1999; Avritzer, 1997).

$\mathrm{O}$ aumento do interesse pelo fenômeno do associativismo ${ }^{1}$ está também interligado com o reconhecimento dos impactos dos fenômenos da globalização, da complexidade e da pluralização na reconstituição das identidades, práticas e repertórios da ação coletiva (Warren, 2001). A crescente interdependência entre os Estados-nação, o desenvolvimento dos mercados globais, as questões ambientais que atravessam fronteiras nacionais, as novas tecnologias e meios de comunicação são, entre tantos outros, aspectos da globalização que se desenvolvem vis-à-vis à proliferação de novas instituiçōes políticas e de organizações sociais. A articulação de demandas locais, nacionais e transnacionais provoca mudanças sociais e políticas que desafiam os aportes conceituais e explicativos da teoria democrática, seja pelo questionamento da capacidade dos Estados em coordenar e mediar as demandas e conflitos sociais, seja pelo processo crescente de pluralização da vida associativa e dos espaços da política, o que alarga e complexifica o lócus da representação política institucional por meio de bases que transcendem os limites territoriais do modelo eleitoral (Urbinati e Warren, 2008).

Diante desse cenário, avolumam-se os estudos e os debates sobre o papel das associações para o desenvolvimento da democracia das sociedades. Partindo-se do pressuposto geral de que um sistema político é mais democrático quando as suas instituições oferecem oportunidades mais igualitárias para os cidadãos tomarem parte das decisóes políticas e dos julgamentos coletivos (Warren, 2001), o papel e os impactos das associaçôes se desdobram em diversas - e não necessariamente cumulativas possibilidades, com destaque para três conjuntos de contribuições: no desenvolvimento individual, contribuindo para a formação, o aumento e o suporte na formação de cidadãos mais democráticos, especialmente em sua capacidade de produzir julgamentos autônomos; na formação da opinião pública construindo, ampliando e problematizando as opiniões e políticas; no fortalecimento das instituições de representação, além da criação de canais institucionais que produzam, via participação dos cidadãos, decisões políticas legítimas. Por meio da representação política, da pressão, da resistência, da participação ou da cooperação, o fato é que, diante dessa paisagem complexa e plural que conforma as sociedades contemporâneas, a democracia se fortalece quando contemplada por um quadro rico e plural de práticas e dinâmicas associativas atuando em diversas tarefas, cooperativas e/ou conflitivas, que ampliam e diversificam as demandas e as respostas democráticas para as diferenciadas necessidades e conflitos políticos e sociais. É este o sentido geral da ideia de "ecologia democrática das associaçôes" (Idem).

No entanto, convém alertar que certo consenso acerca das relações positivas entre associativismo e democracia carrega um alto grau de generalização sobre os impactos democráticos das associaçôes, sem maiores cuidados no que se refere à necessidade de se especificar, no interior desse campo complexo e plural, os diferentes tipos de associações e seus distintos, e muitas vezes contraditórios, efeitos democráticos. Alguns autores (Paxton, 2002; Stolle e Rochon, 1998; Baggetta, 2009; Robteutscher, 2005; Fung, 2003; Chambers e Kopstein, 2001 e 2006; Dagnino, Olvera e Panfichi, 2006) vêm procurando desagregar esse fenômeno, com destaque para o trabalho de Warren (2001), pois reconhecem que muitas associações não são boas para a democracia, como determinados grupos privados, grupos racistas, de ódio, e muitos grupos de interesses poderosos que fazem jus às suspeitas de facciosismo levantadas por Madison e Rousseau em suas preocupações com o ideal do bem comum (Idem, p. 10).

Em que pese esse reconhecimento - e a grande dificuldade de construir um quadro teórico frente à diversidade do mundo associativo -, é possível, de acordo com Warren, construir uma teoria das associações no interior da teoria democrática que 
permita distinguir os seus diferentes papéis e impactos para a democracia (Idem, p.12). De fato, a ideia de ecologia parece proporcionar ganhos analíticos importantes, na medida em que não apenas expande o olhar para um conjunto mais amplo de práticas associativas, mas também identifica diferenças substantivas entre elas, evitando os riscos de se apontar efeitos democráticos onde eles não existem, especialmente quando se considera o fenômeno associativo de forma abstrata e generalizante.

Nesse sentido, os avanços na construção de marcos analíticos que permitam capturar a pluralidade do fenômeno associativo implicam identificar as ambiguidades e os limites desse campo de ação social, suas desigualdades de poder e de recursos e as influências dos respectivos contextos e das relações que estabelecem com outros atores e instituições políticas, econômicas e sociais.

Ressaltamos que a literatura sobre as relações entre associaçôes e democracia é ampla e plural, abrigando diferentes perspectivas que retratam, sob marcos analíticos distintos, determinadas qualidades democráticas das associações. Reconhecendo a abrangência e a pluralidade dessas vertentes analíticas, o artigo concentra três perspectivas teóricas que se dedicam cada qual em atribuir determinados benefícios democráticos às associações, enfatizando, portanto, determinados atributos em detrimento de outros. A escolha dos três conceitos - capital social, sociedade civil e movimentos sociais - é justificada, respectivamente: pelo lugar preponderante que eles ocupam na literatura brasileira sobre as práticas de ação coletiva; por privilegiarem diferentes benefícios democráticos das associações e/ou práticas coletivas - ou seja, cada vertente enfatiza determinados atributos de acordo com as influências e o enquadramento teórico mais abrangente; por fim, por acomodarem, de forma mais explícita, a importância e o papel das associaçôes no interior dos respectivos quadros conceituais.

Convém ressaltar a própria complexidade e pluralidade de cada uma dessas vertentes teóricas, que abrigam disputas, debates e tensões. ${ }^{2}$ Para citarmos um exemplo, no campo das teorias da sociedade civil, perspectivas de matriz gramsciana acusam a perda de potência transformadora da vertente habermasiana, em especial por separar o campo social do campo de atuação política, e, portanto, do poder político-governamental. As teorias dos movimentos sociais, em que pesem as recentes propostas de síntese teórica (McAdam, McCarthy e Zald, 2008), conformam famílias teóricas distintas (Alonso, 2009) 3 ou paradigmas que se debruçam sobre diferentes tipos de ação coletiva ou atores sociais. Além de disputas, há também articulações e diálogos entre essas matrizes, a exemplo das aproximaçôes entre a teoria do capital social de Putnam, da teoria da sociedade civil de Arato e Cohen - que compartilham o resgate das contribuições originais de Tocqueville - ou do reconhecimento, por parte destes, da importância dos movimentos sociais, entre várias outras articulações dessas perspectivas.

Diante desse quadro, nosso objetivo central é resgatar as matrizes que, no interior de cada uma das três linhas teóricas apresentadas, apontam de forma mais incisiva os benefícios democráticos das associações. Esse resgate permite uma ampliação do olhar em dois sentidos: amplia as lentes do campo associativo, incorporando uma diversidade de práticas que, de outra forma, não encontram guarida se pensadas em uma única vertente; amplia o foco para além das formas organizativas dos agentes sociais, ressaltando, à luz de contribuições dessa literatura, a importância dos respectivos contextos e das relaçôes políticas e sociais.

Este texto está dividido em quatro itens. Os três primeiros apresentam as bases mais gerais das vertentes analíticas, procurando identificar: a) os principais atributos e mecanismos democráticos que são depositados, em cada uma delas, a determinados grupos, associações e/ou movimentos sociais; b) algumas de suas limitações, se quisermos tratar o campo associativo a partir da ideia de ecologia. A abordagem do capital social remonta à classica análise de Tocqueville em $A$ democracia na América (1987), dando especial atenção à importância da vida associativa em geral e, mais particularmente, à capacidade das associaçôes gerarem padrôes de civilidade nos cidadãos. A segunda abordagem advém do campo teórico dos movimentos sociais. Em vez de se centrar, como na perspectiva anterior, nos atributos da confiança e da cooperação, a ênfase recai sobre as relações de conflito e de contestação. Embora em estreita articulação com essas 
duas abordagens, a perspectiva analítica da sociedade civil não apenas incorpora as dimensões e os potenciais democráticos apontados nas vertentes anteriores como faz ampliar, no conjunto, o rol dos efeitos democráticos das associações, ressaltando os seus impactos na esfera pública.

O quarto item apresenta os pressupostos gerais da ideia de ecologia democrática das associaçôes, introduzindo uma definição que identifica a influência de Tocqueville (1987) para a sedimentação de uma noção voluntarista e autonomista desse fenômeno social. Essa influência é responsável, em boa medida, pela construção de um sistema de classificação que, ao destacar a importância das "associaçōes secundárias” para a democracia, limitou um olhar mais abrangente, plural e relacional. A fim de compreender o fenômeno do associativismo, além do reconhecimento de outros grupos e organizações, demonstra-se a importância de transcender uma dimensão que, voltada aos agentes - seus recursos, perfis, trajetórias, objetivos e propostas -, perde fôlego se desconsiderar as dimensóes dos contextos e das dinâmicas das relações políticas e sociais. Tais elementos são identificados de diferentes maneiras na literatura. Por exemplo, se uma vertente da teoria dos movimentos sociais (teoria dos processos políticos) indica força explicativa para o contexto político na conformação das práticas coletivas, a perspectiva do capital social registra a influência do contexto social, econômico e cultural. No campo que privilegia a perspectiva das relações ou redes sociais, avolumam-se os estudos que miram as dinâmicas e as relações não apenas entre os atores sociais, mas também entre estes e as instituições políticas (Goldstone, 2003), ou entre o Estado e a sociedade civil (Silva, 2006; Houtzager, Lavalle e Acharya, 2004; Dagnino, Olvera e Panfichi, 2006; Abers e Bullow, 2011).

Com base na apresentação das principais contribuiçōes e características dessas três vertentes, nosso propósito geral é reconhecer a importância de diferentes tipos, tamanhos, configurações e relações associativas concordando com o pressuposto de que conhecer e conceituar esse terreno é uma das mais significativas tarefas para aqueles que acreditam que a democracia pode, ainda, ser expandida e aprofundada (cf. Warren, 2001, p. 13).

\section{Associativismo, capital social e cooperação democrática}

As relações entre o associativismo e a democracia extrapolam, de acordo com importante vertente da literatura, o reconhecimento do princípio básico democrático da liberdade associativa, pois são vistas como constitutivas de processos de fortalecimento mútuo e interdependente. Com efeito, as assertivas a respeito da importância democrática das práticas associativas estão ancoradas na compreensão de que, para além do direito individual de associação, o associativismo preencheria de forma substantiva uma boa quantidade de requisitos considerados fundamentais para estabelecer uma sociedade democrática: por sua capacidade de defender as demandas dos grupos mais vulneráveis e excluídos (Cohen, 1999); pelo caráter pedagógico da promoção de virtudes cívicas, de confiança, cooperação e espírito público (Putnam, 1996); por denunciar as relaçôes de poder; ou, ainda, por promover e ocupar os espaços de cogestão de políticas públicas, enriquecendo as bases da participação e da representação política nas democracias contemporâneas (Fung, 2003).

Uma vertente analítica de grande influência acerca do associativismo tem revigorado os pressupostos encontrados em Tocqueville (1987). ${ }^{4}$ Estudos como os de Almond e Verba (1963) e Nie e Verba (1972) encontraram diferenças consistentes no comportamento cívico - maior interesse em política, maior compromisso, confiança e eficácia política etc. - entre os indivíduos que participam e os que não participam de associações voluntárias, com notável vantagem para os primeiros.

Robert Putnam é uma referência fundamental nessa linha interpretativa, pois seus estudos apontam o peso do capital social e, mais especificamente, das associações para a promoção de redes de engajamento cívico que são centrais para a vida democrática. No trabalho em que analisa o processo de descentralização político-administrativa na Itália, Putnam (1996) enfatiza a comunidade cívica, caracterizada por uma rica vida associativa e por um maior comprometimento da população com as questôes públicas, como um fator determinante para o melhor desempenho governamental. 
De acordo com ele, "o principal fator que explica o bom desempenho de um governo é certamente até que ponto a vida social e política de uma região se aproxima do ideal de comunidade cívica" (Idem, p. 132). Um dos ingredientes principais da comunidade cívica é o associativismo voluntário, que limita - em uma leitura tocquevilleana - $\mathrm{o}$ individualismo e a desconfiança que são corrosivos à sociedade democrática, desenvolvendo comportamentos e atitudes pautadas na solidariedade e no engajamento comum.

Comparecimento às urnas, leitura de jornais, participação em corais e clubes de futebol - estas foram as marcas de uma regiáo bem sucedida. De fato, a análise histórica sugere que essas redes de reciprocidade organizada e de solidariedade cívica, longe de serem um epifenômeno da modernização socioeconômica, foram uma pré-condição para ela - "capital social" refere-se a características de organização social como redes, normas e confiança social que facilitam a coordenação e a cooperação para o benefício mútuo (Putnam, 1995, p. 67).5

O papel das associações para o desenvolvimento dessas virtudes democráticas - cooperação, confiança, comunicação e espírito público - é central. Para essa vertente analítica, as redes associativas ou de engajamento cívico reduzem os comportamentos oportunistas, desenvolvem um senso de pertencimento coletivo e produzem práticas de colaboração que são sustentáculos da vida democrática. Há, aqui, uma clara preferência por um tipo de associativismo, o de base mais horizontal e de expressão face a face. Associações verticais são excluídas como forma de capital social pelo fato de tenderem a promover o oportunismo e reproduzirem relaçôes de poder - entre patrōes e clientes - que são impeditivas de processos cooperativos (Herreros, 2000).

Diferente de perspectivas que vislumbram um papel ativo das associações na formulação de propostas e políticas governamentais, como é a vertente teórica da democracia associativa, ${ }^{6}$ aqui, o modelo da democracia representativa mantém reservas a uma atuação mais ativa do associativismo, sugerindo que os vínculos entre associativis- mo e democracia ocorrem de forma indireta, mais como subprodutos da configuração das relaçōes na estrutura social. De acordo com Beaudoin (2011), o conceito de capital social tem como suporte os elementos das estruturas sociais que possibilitam determinadas conexões e açōes que, em conjunto, impactam sobre as instituiçôes políticas mais gerais. Em especial, o conceito diz respeito à existência de redes de conexôes essenciais para o desenvolvimento de práticas e comportamentos que transcendem a dimensão individual. Essas redes são, portanto, recursos sociais que permitem a conexão entre os indivíduos, estimulando relações baseadas na confiança e na transcendência da esfera estritamente individual. Daí a importância de associações que promovem os encontros face a face ou das associações secundárias, por permitirem o desenvolvimento dessas conexōes.

Nessa perspectiva, quanto mais ricas as redes e conexôes que operam nas estruturas sociais, mais chances de causar impactos positivos na democracia, tornando as instituições políticas mais eficazes. A existência dessas redes permite que os indivíduos acessem esses recursos sociais na constituição de relaçôes que beneficiam outros indivíduos. Por esses mecanismos - as redes e conexões - as normas de reciprocidade e de confiança tendem a se desenvolver na direção das virtudes cívicas, estimulando sensos de coletividade, sendo esta a chave da relação entre capital social, associativismo e democracia.

Por uma variedade de razões, a vida é mais fácil numa comunidade abençoada por um estoque substantivo de capital social. Em primeiro lugar, as redes de engajamento cívico promovem normas robustas de reciprocidade generalizada e encorajam a emergência da confiança social. Essas redes facilitam a coordenação e a comunicação, amplificando respeitabilidades e, assim, permitindo a resolução de dilemas de ação coletiva. Quando as negociações políticas e econômicas estão inseridas em densas redes de interação social, os incentivos para o oportunismo são reduzidos [...] Finalmente, densas redes de interação provavelmente ampliam o sentido do self dos participantes, desenvolvendo o "eu" dentro do "nós", ou (na linguagem dos teóri- 
cos da escolha racional) aumentando, nos participantes, o "gosto" pelos benefícios coletivos (Putnam, 1995, p. 67, tradução da autora).

Ocupando uma posição central no conceito de capital social, as associações constituem recurso imprescindível na construção de conexões e relações baseadas em laços de solidariedade, confiança e de reciprocidade, elementos centrais na formação de atitudes e práticas de base cooperativa. Elas estimulam o interesse e a responsabilidade com os assuntos públicos e, como corolário, impactam o funcionamento das instituições e da própria democracia. Aqui, não apenas os indivíduos, mas a sociedade toda ganha com o capital social. No plano individual, os ganhos do capital social dizem respeito ao fato de que a participação e o envolvimento grupal contribuem para a saúde e o bem-estar individual, além de promoverem o desenvolvimento de cidadãos mais bem informados e preocupados com a vida em sociedade.

Em que pesem as importantes contribuições analíticas dessa abordagem, uma quantidade expressiva de críticas veio à tona, destacando-se aqui, conforme o recorte do artigo, aquelas que reclamam da necessidade de qualificar o caráter associativo e participativo que está embutido no conceito de capital social; e da ausência de mediações nas relações que são estabelecidas entre capital social, comunidade cívica e democracia. No primeiro caso, as críticas estão, em boa medida, ancoradas na avaliação de que as redes horizontais e as associações da sociedade civil são desiguais, apresentando diferenças no acesso aos recursos e estruturas de poder. Putnam é acusado de não fazer distinção entre os diferentes tipos de associação (clubes, ligas esportivas, sindicatos etc.) que são apresentados como de interesse e importância para toda a sociedade. A relação direta entre capital social e comunidade cívica supõe uma homogeneidade da sociedade civil que negligencia relações de poder e de conflitos no interior desse campo (Beall, 1997; Bryceson, 2000).

As relações tecidas entre capital social, civismo e democracia são então questionadas, em boa medida pelo fato de que a idealização (tocquevilliana) de associação civil negligencia a própria definição de comunidade cívica. De acordo com Putzel
(1997), não existe uma relação direta entre capital social e democracia, ou entre a existência de mecanismos de confiança e reciprocidade (operação de redes, normas etc.) e o conteúdo das ideias políticas transmitidas por essas redes. As redes e normas de confiança podem facilitar a troca, reduzir os riscos e tornar o comportamento mais previsível, mas sua contribuição para a democracia depende mais dos projetos e ideais políticos. Segundo Putzel, a comunidade cívica requer um engajamento ou uma participação ativa nas questões públicas; requer a noção de igualdade política ou de cidadania como direitos e obrigações iguais para todos. Nesse sentido, as associaçôes terciárias - caracterizadas pela grandeza e complexidade organizativa, pela diminuição (ou ausência) de laços fortes e por tratar de grandes questôes, como as desigualdades sociais, as disparidades de poder, as políticas sociais (saúde, educação etc.) - são fundamentais para o desenvolvimento democrático das sociedades (cf. Skocpol, 2003).

Ademais, permanecem obscuros os caminhos nos quais as formas de engajamento no nível micro trafegam para o nível macro do sistema, impactando positivamente sobre os processos e dinâmicas da democracia representativa (Peruzzotti, 2008). A ênfase dada ao caráter cooperativo, à confiança, à solidariedade e à tolerância também tem sido motivo para o questionamento dessa dimensão teórica que, ao negligenciar as dinâmicas conflitivas das relações sociais, deixa descoberto todo um conjunto de práticas e de atores sociais (Szasz, 1995). É mirando exatamente a dimensão conflitiva das açôes coletivas que se resgata, aqui, a vertente teórica dos movimentos sociais.

\section{Movimentos sociais, associativismo e conflitos}

De acordo com Diani e Bison (2010, p. 220), os movimentos sociais constituem-se como "redes de interaçôes informais entre uma pluralidade de indivíduos, grupos ou associações engajados em um conflito político ou cultural, com base em uma identidade coletiva compartilhada". É na combinação dessas três características que está assentada, no plano analítico, a especificidade 
dos movimentos sociais frente a outros tipos de ação ou de organização coletiva. As sociedades contemporâneas testemunham - diferente dos "velhos movimentos sociais" revolucionários, centrados na divisão das classes sociais e na figura das classes trabalhadoras como protagonistas dos movimentos sociais - múltiplos eixos de conflitos que perpassam diferentes fontes de poder e de autoridade, e que articulam diferentes identidades sociais. Apesar das variações teóricas sobre os movimentos sociais, o que parece consensual, nessa literatura, é a dimensão contenciosa, ou o caráter de mudança que está embutido nesse tipo de ação social.

[...] a experiência dos movimentos sociais está inextricavelmente ligada à expressão pública de um conflito social. A ação coletiva não somente se orienta para o trato de problemas coletivos, para corrigir injustiças, conquistar bens públicos, atacar fontes de descontentamento, ou expressar apoio a certos valores ou princípios morais; ela o faz identificando alvos para os esforços coletivos, especificamente articulados em termos sociais ou políticos (Diani e Bison, 2010, p. 221).

Com efeito, duas características se destacam no interior dessa vertente analítica. Em primeiro lugar, o caráter conflituoso e contencioso dos movimentos sociais demarca as especificidades dessas ações coletivas diante do campo do associativismo mais geral; em segundo, os movimentos sociais são mais do que simples associações como formas de organização grupal com identidades e objetivos bem formulados. Movimentos sociais constituem-se, fundamentalmente, por meio de articulação, ou seja, não são estruturas homogêneas e bem definidas, ou personagens com identidades claras e fixas, mas "fenômenos heterogêneos e fragmentados que devem destinar muitos dos seus recursos para gerir a complexidade e a diferenciação que os constitui" (Melucci, 2001, p. 29). ${ }^{8}$

Assim, as associações são partes constitutivas dos movimentos sociais, embora não se confundam com eles, os quais incorporam diferentes sujeitos e relações. Poderíamos dizer que as associações são exemplo paradigmático do que a literatura identi- fica como "estruturas mobilizadoras", fazendo referência a uma importante produção teórica sobre os movimentos sociais que se desenvolve no sentido de combinar diferentes perspectivas e conceitos sobre a ação coletiva. McAdam, McCarthy e Zald (2008) apresentam uma proposta de síntese que combina os três conceitos que consideram mais significativos na análise dos movimentos sociais: a estrutura de oportunidades políticas; as formas de organização disponíveis aos insurgentes, ou "estruturas mobilizadoras"; e os quadros interpretativos da ação coletiva. Associações e/ou organizações são centrais e podem ser consideradas um dos principais recursos da ação movimentalista, embora não se confundam com a mesma, na medida em que formam uma importante base daquilo que a literatura dos movimentos sociais conceitua como estruturas mobilizadoras (McAdam; McCarthy; Zald, 2008). Este conceito parte do pressuposto de que os movimentos sociais dependem das oportunidades políticas e dos significados ou quadros interpretativos (frames) dos sujeitos sociais para o desencadeamento da ação coletiva, potencializada de forma significativa pela existência de estruturas de organizaçôes prévias que dão suporte, fornecem modelos $e$, fundamentalmente, constroem novos significados e bases de argumentos. Este é o caso de ONGs, sindicatos, partidos políticos, igrejas, associaçôes de natureza diversa. $\mathrm{O}$ associativismo é um elemento importante na medida em que desloca as atribuições dos problemas e condições do plano pessoal para o coletivo - ou sistêmico -, requisito essencial para o desencadeamento de um movimento social. Assim, em associação, as pessoas desenvolvem sentidos e percepçôes da vida social que transcendem a dimensão individual e pessoal. Aqui, as bases de aprendizado superam muito as expectativas de civismo e cooperação, ao buscarem alterar o status quo nas diferentes dimensões da vida social. Questionar códigos culturais e comportamentos sociais, para além de impactar sistemas políticos e/ou econômicos, é um registro central de diferenciação em relação a abordagens que apregoam a importância da confiança e da integração. Nessa vertente, as principais funções democráticas dos movimentos sociais estão na sua capacidade de alterar a realidade social, seja no plano cultural, seja no institucional, no sen- 
tido de expor e lutar contra as relações de poder e de dominação que caracterizam as diferentes esferas e espaços da vida social.

Um dos mais valiosos aspectos desse tipo de prática associativa é sua capacidade de gerar inovação política e cultural por meio de ações que desafiam as crenças e instituições existentes (Peruzzotti, 2006, p. 52); ações levadas a cabo por diferentes atores e associaçóes que cruzam e combinam, de forma complexa, perspectivas e identidades na construção de novos quadros interpretativos e novos repertórios de ação política. Assim, uma das principais atribuições dos movimentos sociais é a de questionar, renomear e resignificar os entendimentos acerca de determinada realidade social, rompendo com sua (suposta) particularidade ou naturalidade. Quando os atores sociais são bem-sucedidos nessa tarefa de "tradução", os movimentos "iniciam uma conversação com a sociedade e atraem a atenção dos seus membros para uma compreensão mais global de sua causa. Quando isso acontece, o problema e o grupo que o aciona entram definitivamente na vida pública" (Alexander, 1998, p. 27).

Essa perspectiva teórica preenche, portanto, uma importante lacuna se quisermos pensar o campo associativo de forma mais ampla e plural, pois aponta para determinadas práticas coletivas que produzem efeitos democráticos exatamente por sua natureza conflitiva. Como vimos, os mecanismos que permitem operacionalizar benefícios democráticos das associações dizem respeito à capacidade de mobilização e veiculação de mensagens por meio de repertórios que sejam capazes de desestabilizar o ordenamento social. Os benefícios democráticos estão, portanto, voltados para a explicitação de estruturas e relações de poder, desnudando práticas de opressão, controle e discriminação nos planos social, político, econômico e cultural. A noção de repertório permite perceber variadas escolhas e práticas políticas não apenas entre diferentes associações ou organizações, mas também no interior delas, que mobilizam estratégias de ação política e social de acordo com as suas demandas, os espaços institucionais disponíveis, os vínculos e apoios, os seus objetivos e recursos. Piquetes, marchas, demonstraçôes, ocupações, bloqueios, abaixo-assinados, panfletagem, reuniōes públicas, cartas, declarações na imprensa, lobbies e criação de associações figuram entre os mais conhecidos repertórios de ação dos movimentos sociais (Tilly, 2006, p. 53). As diferentes condições ou situações desempenham papel decisivo nas estratégias adotadas, as quais sofrem alterações à medida que essas condições, capacidades e restriçôes se desenvolvem.

Salientamos a importância dos suportes e estruturas - materiais e cognitivas - providos por associações na formação de movimentos sociais. Embora um movimento social seja "uma ação coletiva cuja orientação comporta solidariedade, manifesta um conflito e implica a ruptura dos limites de compatibilidade do sistema ao qual a ação se refere" (Melucci, 2001, p. 35), cada movimento estabelece um sistema multipolar de ação, isto é, operam na constituição e ação dos movimentos sociais não apenas agentes e finalidades, mas meios, recursos e ambientes e/ou contextos. Como mecanismo central na composição desses movimentos, age o processo de construção de identidades, as quais são forjadas pelas articulações desses diferentes elementos: atores, estruturas sociais e políticas e recursos.

Diferentemente, portanto, da perspectiva do capital social, a ênfase recai sobre a dimensão conflitiva das açôes coletivas, a qual, se por um lado ilumina um conjunto de articulações e associações que usam repertórios disruptivos da ordem social, por outro impede um olhar para um campo mais amplo de práticas associativas, mais ou menos institucionalizadas, as quais operam por outras vias, em processos de mudanças sociais. De outra forma, a ênfase na dimensão contestadora e articulatória dos movimentos sociais pode obscurecer não apenas a importância de determinados grupos e atores que são centrais em sua constituição, mas também as articulaçôes - ou sua interdependência - com outros atores e setores que transcendem a esfera social, como as articulaçôes com atores e setores da esfera estatal (Abers e Bullow, 2011).

\section{Sociedade civil, associaçôes e democracia}

Em estreita articulação com as vertentes anteriores, a terceira, representada fundamentalmente por Arato e Cohen (1992) e Habermas (1997), 
procura renovar a teoria democrática por meio da reconstrução do conceito de sociedade civil que, preenchido prioritariamente pelas organizações civis e movimentos sociais, constitui o núcleo na tematização pública de novas questões e problemas, na luta por justiça social e na organização e representação dos interesses dos que são excluídos dos debates e deliberaçôes políticas. Aqui, a relação intrínseca entre sociedade civil e associativismo está ancorada na tese de que as associações civis são as instituições especializadas e responsáveis por reproduzir culturas e tradições e formar identidades coletivas e práticas ancoradas nos princípios da democracia e da solidariedade (Arato e Cohen, 1992). Essa atualização do conceito de sociedade civil absorve diferentes perspectivas analíticas.

Movimentos sociais no Leste e no Ocidente, no Norte e no Sul têm se apoiado em tipos interessantes, embora ecléticos, de síntese, herdados da história do conceito de sociedade civil. Eles pressupõem, em diferentes combinações, algo da divisão gramsciana tripartite entre sociedade civil, estado e mercado, ao mesmo tempo que preservam aspectos-chave da crítica marxista à sociedade burguesa. Eles também reivindicam a defesa liberal dos direitos civis, a ênfase dada por Hegel, Tocqueville e outros à pluralidade societária, a importância dada por Durkheim ao componente da solidariedade social e a defesa da esfera pública e da participação política acentuados por Habermas e Hannah Arendt (Arato e Cohen, 1994, p. 150).

Através do resgate desses pressupostos, Arato e Cohen elaboram um conceito de sociedade civil como um terreno ou campo que, embora articulado e ameaçado pelas lógicas do Estado e do mercado, configura o espaço para expansão ou aprofundamento da democracia nos regimes liberais. Os autores partem do modelo de diferenciação entre sistema e mundo da vida, desenvolvido por Habermas, sistematizando um conjunto de pressupostos que permitem elevar a sociedade civil ao status de "esfera das virtudes democráticas" (Idem).

$\mathrm{Na}$ teoria da ação comunicativa, Habermas (1987) apresenta uma diferenciação entre sistema e mundo da vida como diagnóstico dos problemas contemporâneos. O sistema é composto por dois subsistemas: o Estado e o mercado. Os mecanismos de coordenação da ação nesses subsistemas são respectivamente o poder e o dinheiro, caracterizando, portanto, uma ação baseada na racionalidade estratégica e/ou instrumental. Já o mundo da vida caracteriza-se, em boa medida, pela ação comunicativa: trata-se da esfera das tradiçōes, da cultura compartilhada, da solidariedade e da cooperação.

[...] o agir comunicativo distingue-se, pois, do estratégico, uma vez que a coordenação bem-sucedida da ação não está apoiada na racionalidade teleológica dos planos individuais de ação, mas na força racionalmente motivadora dos atos de entendimento, portanto, numa racionalidade que se manifeste nas condições requeridas para um acordo obtido comunicativamente (Habermas, 1990, p. 72).

O processo de modernização provocou um desequilíbrio na integração dessas esferas, com a colonização do mundo da vida pela racionalidade dos dois subsistemas. Se o mundo da vida é responsável pela integração social, o sistema, baseado na ação estratégica, é responsável pela integração sistêmica: ele deve assegurar a reprodução material e institucional da sociedade. A crise significa o desengate entre essas duas racionalidades, com o predomínio e a expansão das relações de poder e da lógica do mercado sobre as relaçóes sociais. Nesse processo de diferenciação, desenvolvem-se instituições responsáveis e especializadas na reprodução de culturas, tradições, identidades e solidariedades. Essas instituiçôes correspondem à esfera da sociedade civil, e apresentam como característica básica uma práxis comunicativa voltada para o entendimento - em especial quando abrigadas pelas garantias dos complexos de direitos dos Estados liberal-democráticos, ${ }^{9}$ que rompem com as ordens baseadas em fundamentalismos e tradiçốes.

A associação é um importante mecanismo de articulação de estratégias tanto defensivas quanto ofensivas, ou seja, comporta uma tarefa dupla da democracia radical autolimitada: "a aquisição pelo público de influência sobre o Estado e a economia; 
a institucionalização dos ganhos dos movimentos sociais dentro do mundo da vida" (Arato e Cohen, 1994, p. 174). As associações e os movimentos sociais são os sujeitos ativos e públicos de uma sociedade civil modernizada cuja democratização opera em duas frentes: a dos valores e práticas sociais; a dos subsistemas e práticas institucionais.

Assim, para essa perspectiva, a sociedade civil constitui um conjunto de atores e de instituições que se diferenciam dos partidos e de outras instituiçõos políticas (uma vez que não estão organizados tendo em vista a conquista do poder) e também dos agentes e instituiçôes econômicas (não estão diretamente associados à competição no mercado). Pluralismo, autonomia, solidariedade e influências/impactos na esfera pública completam, portanto, o quadro de características dessa concepção de sociedade civil moderna, que, identificada como modelo utópico autolimitado, procura compatibilizar o núcleo normativo da teoria da democracia com as complexas e diferenciadas estruturas da modernidade.

A publicidade é a principal mediação entre o associativismo e a democracia. De acordo com Habermas (1997, p. 92), "a esfera pública pode ser descrita como uma rede adequada para a comunicação de conteúdos, tomadas de posição e opiniōes; nela, os fluxos comunicacionais são filtrados e sintetizados, a ponto de se condensarem em opiniões públicas enfeixadas em temas específicos”. Assim, essa "esfera pública geral" é responsável pela tematização pública dos problemas e temas que afetam a sociedade, exercendo importante influência na "esfera pública procedimentalmente regulada", responsável, portanto, pela tomada de decisões refletidas pelos interesses e pelas influências da primeira, ou dos fóruns de discussão extrainstitucionais. Compete fundamentalmente à sociedade civil exercer essa influência por meio da constituição e da participação nas esferas públicas gerais.

Embora os movimentos sociais sejam centrais, a ideia de associativismo embutida nessa perspectiva envolve um quadro mais amplo de atores sociais, como organizações não governamentais e diferentes tipos de associações que defendem interesses sociais. $\mathrm{O}$ caráter de mediação entre os problemas vividos pelos diferentes setores da sociedade e os es- paços institucionais da política é o elemento-chave na identificação dos benefícios democráticos das associações. Aqui, como nas vertentes anteriores, a escolha por determinados tipos associativos impede um olhar mais amplo e plural do fenômeno do associativismo, em especial o reconhecimento (democrático) de associações vinculadas ao mundo político e econômico, além de negligenciar as práticas associativas que ocupam um lugar periférico no interior desse campo social. Como resultado, o modelo teórico inibe a identificação de importantes diferenças e desigualdades no interior do próprio campo da sociedade civil (Kerstenetzky, 2003; Gurza Lavalle, 1999 e 2003; Dagnino, Olvera e Panfichi, 2006; Silva, 2006); diferenças que também problematizam quaisquer ideais de uma esfera pública isenta de desigualdades, de estratégias e de poder. De outra forma, o caráter autolimitado da sociedade civil obscurece tanto as relaçōes - políticas, econômicas ou sociais - que são constitutivas das práticas associativas quanto uma atuação mais ativa em articulação com as esferas governamentais.

Grosso modo, cada vertente ressalta determinados tipos de impactos democráticos do associativismo. Como o quadro 1 sistematiza, as três vertentes apontam preferencialmente para determinados atores, mecanismos e impactos - seja no plano do desenvolvimento individual, no do questionamento da ordem social ou, ainda, no da inclusão política - via representação pública de temas e demandas sociais. Se pensarmos a democracia como um fenômeno multidimensional, o que implica considerar suas dimensões individuais, sociais, econômicas e político-institucionais, todos os diferentes impactos aventados nessas correntes teóricas são bem-vindos. A essa receptividade corresponde a ideia de ecologia democrática das associaçôes, que reclama uma síntese entre as diversas teorias existentes.

\section{Significados e características das associaçóes}

Há certamente uma grande dificuldade para uma definição precisa de associação, a ponto de nos perguntarmos se seria possível, ante a multiplicidade de práticas associativas, estabelecer características gerais que permitam algumas distinções sem 


\section{Quadro 1}

\section{Síntese dos Tipos Associativos e seus Efeitos Democráticos}

\begin{tabular}{|c|c|c|}
\hline Capital social & Movimentos sociais & Sociedade civil \\
\hline $\begin{array}{l}\text { As associações são organizações } \\
\text { voluntáiias, autônomas e sem } \\
\text { fins lucrativos, que promovem a } \\
\text { coordenação e a cooperação para } \\
\text { o benefício mútuo. Ênfase nas } \\
\text { associações face a face. }\end{array}$ & $\begin{array}{l}\text { As associações fazem parte de redes } \\
\text { de interaçôes engajadas em conflitos } \\
\text { políticos, sociais ou culturais, com } \\
\text { base em uma identidade coletiva } \\
\text { compartilhada. Ênfase nas associações } \\
\text { que contestam a ordem social. }\end{array}$ & $\begin{array}{l}\text { As associações atuam pela lógica da } \\
\text { ação comunicativa e são autônomas } \\
\text { do mundo político e econômico. } \\
\text { Pretendem, sobretudo, influenciar } \\
\text { as decisões políticas institucionais. } \\
\text { Ênfase nas associações de defesa de } \\
\text { direitos e movimentos sociais. }\end{array}$ \\
\hline $\begin{array}{l}\text { Impactos democráticos: promoção } \\
\text { de virtudes democráticas no plano } \\
\text { individual e social; confiança, } \\
\text { solidariedade e espírito cívico; ênfase } \\
\text { na cooperação. }\end{array}$ & $\begin{array}{l}\text { Impactos democráticos: promoção } \\
\text { de mudanças nas relações de poder, } \\
\text { tanto no plano político-institucional } \\
\text { como no plano cultural; ênfase na } \\
\text { contestação e no conflito. }\end{array}$ & $\begin{array}{l}\text { Impactos democráticos: inclusão de } \\
\text { atores e temas no mundo político } \\
\text { através da tematização pública de } \\
\text { problemas sociais; ênfase na mediação } \\
\text { das esferas públicas. }\end{array}$ \\
\hline
\end{tabular}

recair em reduçôes e simplificações. Esse problema pode ser facilmente encontrado nas três perspectivas analíticas apresentadas. Assim, se o conceito de capital social contempla, majoritariamente, as associaçôes face a face (a exemplo de clubes de futebol, corais, grupos de escoteiros, associações comunitárias), as teorias dos movimentos sociais privilegiam as redes e as organizações com expressões mais amplas e que questionam a ordem social. Para a teoria da sociedade civil, a vinculação entre as associaçōes e o mundo da vida minimiza a importância das organizaçôes e grupos que estão mais diretamente inseridos nos campos político e econômico (a exemplo dos partidos e sindicatos). Grosso modo, esses diferentes recortes estão alicerçados em concepçôes distintas de democracia e de organização da vida política e social.

Contudo, há uma noção mais ou menos comum quando falamos de associação. Recuperando os principais autores que analisaram a importância democrática das associaçōes, Warren (2001) ressalta a influência de Tocqueville para sedimentar uma concepção moderna de associação, na medida em que esse autor via as associações secundárias, ${ }^{10} \mathrm{di}$ ferentemente dos vínculos primários, como açōes coletivas benéficas ao cultivo da sensibilidade ética de um "autointeresse bem compreendido", desenvolvendo novas formas democráticas de interação. Warren (Idem, p. 42) aponta duas características do associativismo que são centrais para Tocqueville: a existência de uma relativa igualdade social dos indivíduos; e o grau de voluntarismo na constituição de relaçôes consensuadas, que alteram a sensibilidade ética dos seus membros. São pelo menos dois, também, os pontos de críticas a essa abordagem. Por um lado, a ênfase nas associaçōes secundárias, marcadas por baixo grau de complexidade e alto grau de autonomia. Para o autor, pensar as relaçóes entre associaçōes e democracia requer a inclusão das práticas associativas primárias (a exemplo das famílias, consideradas grupos determinantes na conformação de indivíduos mais cívicos e democráticos) e terciárias (mais abrangentes, hierárquicas e impessoais, a exemplo de partidos políticos e sindicatos). ${ }^{11}$

Por outro lado, mantendo o recorte das associações secundárias, baseadas em relações mais igualitárias e voluntarismo, essa perspectiva impede, em face de uma concepção bipolar de sociedade, ${ }^{12}$ que se percebam tanto as relaçóes de desigualdade e de poder no interior do campo das associaçōes, quanto as relaçōes cada vez mais frequentes entre as associaçōes e outras formas de organização (como o Estado e o mercado) na formação de complexas redes e parcerias que se efetivam por meio da provisão de serviços sociais, de financiamentos públicos e privados, do desenvolvimento de projetos nas diferentes áreas sociais, de inserção de lideranças sociais nos aparelhos do estado, etc. 
Não é à toa que Warren (idem, p. 56) evita o termo sociedade civil, pois, sendo um "conceito setorial", ele impede que se olhe para os diferentes tipos de relações sociais que compõem o mundo associativo. Embora reconheça a riqueza e a história desse conceito, seu uso tende, de acordo com o autor, a reduçôes e simplificaçôes. Por um lado, exclui as relaçôes íntimas entre famílias e amigos, pois estas são tidas como constitutivas do mundo privado em detrimento do mundo civil. ${ }^{13}$ Por outro lado, identifica as qualidades associativas com as organizações voluntárias, quando essas qualidades podem ser também encontradas em outros tipos de organização. Baseado na distinção formulada por Parsons acerca da "estrutura associacional" (ou das relações associativas) como um dos três tipos de organizações operativas nas sociedades modernas, ao lado dos mercados e das burocracias, Warren procura remediar o problema das relaçōes, diferenciando associações de relações associativas.

Associaçôes são organizaçôes cuja força deriva principalmente de relações associativas - isto é, relações baseadas em influência normativa. Relaçôes associativas se referem a um dos três meios gerais de organização da sociedade. Disso resulta que a distinção entre Estado, economia e sociedade civil é de domínio institucional, enquanto que as distinções entre a burocracia, o mercado e as relaçóes associativas referem-se a tipos de organização operativa. Os conjuntos de distinções estão relacionados na medida em que cada tipo de domínio institucional está centrado, por assim dizer, em um tipo de organização operativa, da qual nenhuma instituição é um puro exemplar. Nenhuma instituição pode atuar puramente por meio de operaçôes de mercado, nem através do comando hierárquico. Da mesma forma, poucas associaçôes, por causa dos envolvimentos com o poder e com o dinheiro, exibem as qualidades puramente voluntárias e consensuais das relações associativas (Idem, p. 54).

Da mesma forma que encontramos relações associativas no Estados e nos mercados, encontramos relações políticas e mercadológicas nas associações. Assim, embora o Estado não seja uma associação no sentido ora empregado, relações associativas são encontradas em Estados democráticos, gerando outras bases de legitimidade para a coerção estatal. Por essa via analítica, podemos pensar a sociedade civil como o domínio de associaçôes que são centradas em relações associativas que interagem com Estados, mercados e relações de intimidade (cf. idem, p. 58). Essa natureza relacional se desdobra em duas dimensões que, embora de naturezas diferentes, apresentam importantes correlaçôes. Em primeiro lugar, a dimensão da natureza operativa dos distintos domínios institucionais, apesar de ser eminentemente relacional no campo da sociedade civil, implica que os outros campos institucionais - Estado e economia - também atuem por relaçôes associativas, ainda que a natureza operacional seja ditada pelas lógicas do poder burocrático e das transaçōes de mercado, respectivamente. De outra forma, a natureza das relações associativas da sociedade civil não significaria um bloqueio à sua inserção - e relação - com esses campos institucionais. Isto é, as relações estabelecidas entre esses domínios vai além da dimensão subjetiva, determinada pela vontade, objetivos, estratégias e ações dos atores associativos, a qual corresponde, como veremos, à segunda dimensão relacional.

No plano objetivo - ou de natureza estrutural -, além dos impactos socioeconômicos na configuração da sociedade civil (Chambers e Kopstein, 2001), temos a dimensão da cultura política, da densidade de redes na esfera social, dos impactos das tecnologias de informação e de lazer e da mobilidade econômica e territorial, como destacados pela teoria de capital social. De outra forma, salientam-se também os impactos da configuração do sistema político e institucional nas dinâmicas dos atores sociais. Schneiberg e Lounsbury (2007), por exemplo, apresentam vários estudos identificando diferentes características do campo político e institucional que condicionam as dinâmicas ou o sucesso dos movimentos sociais. Essas características incluem as heranças das políticas prévias, a receptividade das autoridades político-institucionais às demandas e reivindicações, a concentração de recursos no interior do campo institucional de ação coletiva e a prevalência de certos modelos culturais. Como parte desse contexto, há o que a literatura 
de movimentos sociais denomina de estruturas de oportunidades políticas. Tarrow (1999) destaca, entre as estruturas de oportunidades que propiciam a ação coletiva, além das instituições estatais, também as "estruturas de conflito" e as "alianças" que lhe oferecem incentivos e/ou constrangimentos. De acordo com Meyer (2004), as açóes coletivas não ocorrem num vazio; ao contrário, a organização política e o posicionamento dos seus atores promovem diferentes estratégias de ação coletiva. Nessa perspectiva, a "agência", as escolhas, as estratégias e o posicionamentos dos atores coletivos só podem ser compreendidos e avaliados por meio de análises do contexto e das regras do jogo político, isto é, da "estrutura" (Meyer, 2004, p. 128). Conforme Rennó (2003, pp. 74-75), "instituiçōes podem fomentar ação coletiva criando estruturas de oportunidade política para grupos sociais". Nesse sentido, as associaçōes são "artefatos", ou seja, produtos das açôes e relaçôes sociais: dependem das estruturas econômicas e políticas, dos recursos e das instituições. Ademais, podem variar de acordo com a maior centralidade ou não de governos, com as informaçôes disponíveis, as oportunidades e os incentivos (Cohen e Rogers 1995).

Uma segunda dimensão relacional apresenta uma natureza mais subjetiva e também se desdobra em diferentes relaçôes, estabelecidas no campo próprio da sociedade civil ou entre esse campo e o campo dos atores e instituiçóes políticas. No que diz respeito às relaçóes que ocorrem no campo próprio do associativismo, podemos identificar pelo menos três tipos (abstraindo-se especificidades e combinaçōes) de associações: as que se encontram mais isoladas ou com pouco vínculo; as que constroem redes de articulação de base intermediária (a exemplo de organizações de base territorial e regional); as que formam amplas redes articulatórias (a exemplo das redes de movimentos sociais). Os benefícios também podem ser diversos, com o destaque para a capacidade de ampliação e interconexão de problemas e demandas sociais, de ampliação da esfera pública, de resistência, de promoção de habilidades políticas, entre outros. Segundo Schrerer-Warren (2006), as articulações ou redes, caracterizadas por diferentes atores, grupos e organizaçōes, aproximam atores e valores sociais diversos nos di- ferentes níveis, locais, regionais e globais, permitindo o "diálogo da diversidade de interesses e valores. Ainda que esse diálogo não seja isento de conflitos, o encontro e o confronto das reivindicações e lutas referentes a diversos aspectos da cidadania vêm permitindo aos movimentos sociais passarem $\mathrm{da}$ defesa de um sujeito identitário único à defesa de um sujeito plural"14 (Idem, p. 115). Assim, a transversalidade de demandas e de identidades amplia perspectivas e imprime novas vias de interlocução e identificação. Estas, por seu turno, contribuem para romper com paroquialismos ao mesmo tempo que permitem gerenciar conflitos e dialogar com as diferenças. Em pesquisa voltada para a identificação de práticas deliberativas nos movimentos sociais globais, a exemplo do movimento por justiça global, Della Porta (2005) registra a presença de uma pluralidade de atores e de identidades na formação de uma rede pautada, apesar das dificuldades e problemas, no respeito à diferença, na busca de construção de consensos e no valor aos princípios de subjetividade, inclusividade e diversidade.

No que diz respeito às relaçôes com os atores e instituições políticas, podemos identificar também um quadro de múltiplas configuraçōes, com aproximaçōes de diferentes graus e tipos, seja por relaçōes de interesses, de estratégias e/ou de posicionamentos ideológicos. Aqui podemos também apontar pelo menos três tipos de associações. $\mathrm{O}$ primeiro inscreve aquelas que não mantêm relações, por não contarem com objetivos que demandam relações político-institucionais ou por questionarem o poder institucional; neste caso, acusam as suas dimensões instrumentais e adotam posturas mais autonomistas, como são os exemplos de alguns movimentos sociais. $\mathrm{O}$ segundo tipo engloba as associações que mantêm relaçóes estratégicas com governos e partidos com vista a concretizar seus objetivos e demandas. Por fim, compondo o terceiro tipo, há as associaçōes que mantêm relações fortes ancoradas no compartilhamento de projetos políticos (Dagnino, Olvera e Panfichi, 2006).

Assim, a fim de compreender o fenômeno do associativismo, ressalta-se a importância de transcender uma dimensão que, voltada aos agentes - seus recursos, perfis, trajetórias, objetivos e propostas -, perderia fôlego se desconsiderasse as dimensōes dos 
contextos e das relações políticas e sociais. Tendo essas dimensões como norte e sustentando que a democracia envolve procedimentos institucionalizados para garantir a distribuição igual de poder sobre a tomada de decisões e a participação igual nos julgamentos coletivos, sob a proteção dos direitos de expressão, demonstração, argumentação e justificação, Warren (2001, p. 60) sistematiza, como já visto anteriormente, três tipos de efeitos democráticos ${ }^{15}$ que são, potencialmente, produzidos pelas associações: efeitos no plano individual, para prover julgamentos autônomos; efeitos nas esferas públicas, tendo em vista a formação de opiniāo e de julgamentos públicos; efeitos político-institucionais, seja ampliando e qualificando a representação política, seja cooperando para formas alternativas de governança. Como vimos, esses efeitos estão contemplados, de formas variadas, nas três vertentes teóricas apresentadas. No plano individual, os benefícios são diversos e dizem respeito: ao sentimento de eficácia política; à provisão de informação; ao desenvolvimento de habilidades políticas (capacidade de fala, de autoapresentação, de negociação e barganha, de formação de coalisões e de criação de novas soluções, de reconhecimento de manipulação, pressão ou ameaça); de virtudes cívicas; ${ }^{16}$ de habilidades críticas, na formação de capacidades cognitivas para a formação de julgamentos críticos e autônomos (Warren, 2001, pp. 70-76). Reconhecer a pluralidade do campo associativo implica desagregar (ou desempacotar) esses e outros possíveis benefícios. Algumas associações pavimentam processos de formação de lideranças políticas; outras promovem aumento de autoestima; outras ainda viabilizam ganhos de socialização.

$\mathrm{Na}$ esfera pública, destacam-se os benefícos operacionalizados pela comunicação pública e/ou pela deliberação, promovendo maior vínculo social e maior sensibilidade a problemas como pobreza, abusos variados e discriminaçôes. Essa esfera permite, portanto, tanto a representação das diferenças - sendo o argumento público um dos poucos recursos dos mais pobres e fracos perante os setores e associações que dispõem de recursos econômicos, hegemonia cultural, ou prestígio ${ }^{17}$ - quanto a representação da "comunalidade", no sentido de atuar em prol do que é comum a todos os humanos (celebrar datas, por exemplo), reforçando um pertencimento de humanidade (cf. Warren, 2001, pp. 77-82).

Por fim, no plano político-institucional, destaca-se a importância das associações para a ampliação e a qualificação da representação política, demandando accountability dos representantes eleitos ou superando as bases territoriais da representação, cada vez mais estreitas perante a pluralidade de demandas e interesses construídos a partir de diferentes identidades sociais (Lüchmann, 2011; Avritzer, 2007; Gurza Lavalle; Isunza Vera, 2011). O papel de promover resistência é especialmente importante por sua capacidade de persuasão, de provocação e de promoção de mudanças em situações de distribuição desigual de poder. Ressalta-se também a importância de uma atuação de base mais cooperativa junto aos governos, contribuindo para avaliar, propor e deliberar sobre políticas públicas por meio de processos pautados na participação e na estabilização de conflitos. Associações proveem informaçôes, contribuem para a inclusão política e, fundamentalmente, ajudam os governos a administrarem a sociedade (Hirst, 1994 e 2001; Cohen e Rogers, 1995; Elstub, 2007 e 2008).

Warren (2001, p. 94) identifica - embora reconheça a interferência de outras variáveis, a exemplo do tipo de organização e de liderança - três principais características das associações que intercedem de forma significativa para a promoção de diferentes efeitos democráticos. A primeira é o fato de a associação ser mais ou menos voluntária. ${ }^{18} \mathrm{~A}$ segunda são os seus "meios constitutivos" - o social, baseado em normas, costumes, comunicação, solidariedade, como ocorre de forma mais frequente nos grupos sociais, famílias, clubes, igrejas e movimentos sociais; a coerção ditada por leis e pelo poder, como são os casos da constituição de partidos políticos, associaçōes profissionais e corporaçôes; o dinheiro, a exemplo de grupos de lobbies, alguns sindicatos, grupos de empresários, consumidores etc. Entra aqui o caráter de maior ou menor inserção, ou integração, das associações ao meio social. De acordo com Warren (Idem, p. 122), as mais integradas atuam conforme a ordem social dada, diferentemente daquelas que - a exemplo de movimentos sociais ou grupos que lutam contra a discriminação - tendem a usar o poder comunicativo em função da ausência 
de outros recursos. Assim, por estarem inseridas de forma diferenciada na estrutura social, apresentam impactos distintos - e em muitos casos contraditórios - à democracia. A terceira, por fim, são suas propostas, metas, e objetivos. Como assinalamos, embora a maioria das associações não tenha como objetivo a democracia, suas açóes podem trazer benefícios indiretos, como confiança e interação social.

\section{Consideraçóes finais}

É certo que a complexidade de tipos e de combinações entre as associações e os benefícios democráticos dá margem a confusões e novas generalizações. Importa-nos, tendo em vista a contribuição desse debate para o aprodundamento do conhecimento das relaçóes entre democracia e associações, apontar algumas dimensóes.

Em primeiro lugar - lembrando que esta é exatamente a ideia de ecologia democrática das associações - o reconhecimento de que diferentes tipos de associações podem provocar diferentes efeitos democráticos evita se esperar que a mesma associação combine todas as virtudes elencadas, sendo ao mesmo tempo deliberativa, representativa, contenciosa, cultivadora de virtudes cívicas, formadora de opinião etc. Em vez disso, associações que desempenham um tipo de função podem, por várias razões, ser incapazes de exercer outras. Algumas são importantes para o exercício da governança, outras para desenvolver habilidades cívicas ou resitência, e assim por diante. $\mathrm{O}$ problema de generalizar não é apenas apontar efeitos onde eles não existem, como alega Warren, mas o de não enxergar efeitos democráticos em associações que são descartadas, a priori, em função de perspectivas teóricas e ideológicas. ${ }^{19}$ As "associações podem provocar efeitos democráticos similares por razōes diferentes" (idem, p. 141), além de efeitos não democráticos.

Em segundo lugar, há efetivamente uma complexidade de práticas associativas, estando a maioria voltada para objetivos que são bem mais modestos no que se refere às expectativas mais exigentes de atendimento aos pressupostos democráticos. Além disso, associaçôes podem promover ódio, discriminação, intolerância, violência, desigualdades; são criadas pelos indivíduos e setores sociais, econômicos e políticos, obedecendo aos interesses variados e constrastantes, para a reprodução ou a mudança social, para a privatização e/ou manutenção de privilégios, ou ainda para a alteração das relações de poder. Há, portanto, importantes desigualdades, conflitos e relações de poder no interior do campo associativo. Práticas associativas e participação política podem mascarar, em nome do interesse geral ou do bem comum, condições e interesses antidemocráticos. Os riscos de manipulação e de monopolização em função de recursos vinculados a dinheiro, poder e prestígio são constitutivos dessa complexidade social.

Em terceiro lugar, há diferenças substantivas nos impactos democráticos das associações. Em se tratando de países com alto grau de desigualdades sociais, como o Brasil, as associações mais combativas certamente tendem a apresentar maior capacidade democrática do que os corais ou os clubes de futebol. De toda forma, tendo em vista a variedade desse fenômeno, os potenciais benefícios democráticos das associações necessitam ser testados empiricamente, considerando-se seus diferentes contextos sociais. Assim, há que se analisar a variação dos efeitos democráticos das associaçōes em perspectiva comparada, pois um mesmo tipo de associação pode promover efeitos distintos, de acordo com cada contexto. Associações de moradores têm desempenhado, no Brasil, funçôes importantes de representação e de intermediação, tornando-se atores centrais de movimentos sociais, a exemplo do movimento pela reforma urbana - diferentemente das atribuições, digamos, mais cívicas desses atores no cenário associativo norte-americano.

Enfim, entender as configurações do campo associativo requer que se olhe para além das associações, ao mesmo tempo que se identifiquem os recursos, os atores, as propostas e as dinâmicas das práticas associativas em suas relações e articulações, se quisermos avançar nos estudos sobre as relações entre o associativismo e a democracia. Assim, à dimensão dos agentes, como os seus objetivos e a maior ou menor capacidade de articulação, soma-se a configuração das condições culturais, econômicas, políticas e sociais. Devem-se qualificar, em cada caso concreto, essas características 
e relaçôes. Mais ainda, pensar a democracia sob o ponto de vista multidimensional implica avançar na construção de metodologias de avaliação dos resultados concretos dos impactos democráticos das associaçôes.

\section{Notas}

1 De acordo com Warren (2001), o ressurgimento do interesse nas associações atravessa diferentes perspectivas analíticas, a exemplo das perspectivas pluralistas, comunitaristas, liberais, republicanas e democratas, conformando um quadro muito mais amplo e complexo do que o aqui abordado.

2 Perspectivas mais panorâmicas que sistematizam os principais autores e debates no interior de cada vertente podem ser encontradas em Costa (1997), no que diz respeito aos conceitos de sociedade civil, Alonso (2009), sobre as teorias dos movimentos sociais, e Higgins (2005), quanto aos fundamentos teóricos do capital social.

3 A autora analisa três famílias de teorias dos movimentos sociais que se desenvolveram a partir dos anos de 1970: a teoria de mobilização de recursos (TMR), a teoria do processo político (TPP) e a teoria dos novos movimentos sociais (TNMS).

4 Galston (2000) chama a atenção para o aumento do interesse pelas associações voluntárias com a retomada dos escritos de Alexis de Tocqueville.

5 A proposta aqui, então, é tentar extrair, a partir de referências mais gerais de diferentes perspectivas teóricas, as principais contribuições das associações à democracia, muito distante de apresentar as aproximações, diferenças e conflitos no interior - e entre as - vertentes, o que implicaria em um trabalho teórico de muito mais fôlego.

6 De maneira geral, a democracia associativa é considerada um terceiro caminho entre o individualismo do mercado livre e o controle centralizado do Estado, podendo ser definida como um modelo de democracia participativa no qual o ideal de autogoverno é preenchido pelos grupos e associações. Para os seus expoentes (Hirst, 1994 e 2001; Cohen e Rogers, 1995; Elstub, 2007 e 2008), a atuação das associações junto ao Estado permitiria a promoção do ideal do bem comum, configurando um processo de soma positiva por meio do aumento do poder das associaçôes e da maior eficiência do Estado, além do mercado, o que promoveria o fortalecimento da ordem democrática (Lüchmann, 2012).

7 De acordo com Alexander (1998), deve-se a Alain Touraine a elaboração de uma reconstrução histórica dos movimentos sociais "clássicos" (movimentos revolucionários de tomada e controle do poder político), acompanhada da análise da passagem para as sociedades pós-industriais.

8 É nessa perspectiva que Scherer-Warren (2006) define o conceito de movimentos sociais, ou "rede de movimento social", como complexo resultado de articulação de diferentes atores, associações e fóruns que constroem processos de identificação de causas e lutas. Portanto, os movimentos sociais transcendem "as experiências empíricas, concretas, datadas, localizadas dos sujeitos/atores coletivos" (Idem, p. 113).

9 Arato e Cohen (1994) identificam três complexos de direitos: direitos de reprodução cultural (liberdade de pensamento, imprensa, expressão e comunicação), direitos que garantem a integração social (liberdade de associação e reunião) e direitos que garantem a socialização (proteção da privacidade, intimidade e inviolabilidade do indivíduo).

10 De acordo com Warren (2001, p. 39), foi Charles H. Cooley, em Human nature and social order (1964), quem primeiro diferenciou os três tipos de associaçôes de acordo com a natureza dos laços. Assim, famílias e amizades são redes de associação primária, pois desenvolvem relações mais próximas e íntimas. As associações secundárias, embora também próximas, se distanciam do tipo de laços das associações primárias e se voltam para relações que transcendem o mundo individual, como os grupos cívicos, os clubes, as associações religiosas, entre tantas outras. As associações terciárias seriam os grupos de interesses e profissionais, nos quais os membros são relativamente anônimos entre si e têm pouco em comum além de perseguirem uma mesma proposta específica.

11 De fato, esse grau de abrangência apresenta ganhos analíticos na medida em que permite um olhar mais amplo para um conjunto de práticas associativas que não encontram guarida nas teorias voltadas às relaçôes entre associações e democracia. Por outro lado, englobar tipos tão diferentes de associações pode levar a perdas de substância analítica por não apresentar as especificidades que qualificam e diferenciam significativamente esses tipos de prática associativa. Afinal, partidos políticos conformam um tipo de associação que objetiva ocupar os espaços de poder político, algo muito diferente de outras organizações de base social 
e voluntária. Da mesma forma, famílias se constituem sob bases, objetivos e estruturas que transcendem, em muito, as características que identificam os outros tipos de associação. São, portanto, fenômenos muito diferentes, embora não deixem de ser formas associativas e apresentarem contribuiçôes significativas à democracia.

12 Seguindo análise de Warren (2001, p. 32), Tocqueville trabalhou com um modelo bipolar em sua análise das relações entre estado e sociedade civil e concebeu os efeitos institucionais das associações dentro desse modelo, que assume dois meios básicos de organização social: um coercitivo, legal e admistrativo, do Estado; outro, das normas, hábitos culturais, discussão e acordo, que caracterizam as relaçôes não estatais. Nessa visão, o poder recai sobre o Estado, e as interaçōes sociais são encontradas na sociedade, que assimila, sem qualificar suas especificidades estruturais, o mercado.

13 Constituem-se, portanto, em domínios "antipolíticos", que, se colocados no público, corrompem o bem comum. Nesses termos, ressalta Warren (2001), podemos entender por que o conceito de sociedade civil é limitado para o entendimento do terreno associativo da democracia: "É nas relaçôes íntimas que nós esperamos encontrar disposiçōes éticas de reciprocidade, empatia e cuidado que, inseridas nos domínios políticos, podem melhorar a democracia. Concepções espaciais/setoriais obscurecem o que uma concepção relacional de associação torna óbvio" (Idem, p. 57).

14 Entre os exemplos citados, a autora ressalta a Marcha Mundial das Mulheres (MMM) como uma rede interorganizacional que, "no momento de suas mobilizaçôes na praça pública se amplia consideravelmente com a presença de muitos(as) cidadãos(ãs) participantes, como ocorreu no lançamento da Carta Mundial das Mulheres para a Humanidade, em 8 de março de 2005, em São Paulo, onde foi estimada a presença de 30 mil mulheres de dezesseis estados brasileiros e representantes de outros países. A viagem da Carta pelas Américas permite não só uma ação integrada do movimento feminista latino-americano, mas também alianças com o conjunto dos movimentos sociais, em torno de uma pauta multidimensional que foi se construindo à medida que passava pelos vários países: por moradia, pela reforma agrária, por salário justo, saúde, direito ao aborto, pela paz, contra a violência, o racismo, a guerra etc. - agenda esta que vai caracterizando uma face multi-identitária de um feminismo em movimento, latino-americano e mundial" (Scherer-Warren, 2006, p. 116).

$15 \mathrm{O}$ autor justifica essa linguagem funcionalista afirmando que os efeitos/funçôes não são necessaria- mente os propostos ou motivados pelos membros das associações. O ponto geral da abordagem, aqui, parte do pressuposto de que as sociedades e os sistemas políticos não são agregados de disposições de seus membros, mas algo a mais, como a linguagem funcionalista indica. De fato, a grande maioria das associações não tem propostas voltadas à democracia, embora possa promover efeitos democráticos (ou antidemocráticos). Essa linguagem também permite superar a ideia de que as associações são boas somente se elas têm metas e bens democráticos. Associaçôes podem e devem ser julgadas por outros efeitos, como o amor, a amizade, a beleza ou a lealdade (Warren, 2001).

16 Virtudes voltadas aos ideais de bem comum, justiça, tolerância a outras visões, confiança, deliberação, cooperação, reciprocidade, respeito às leis e direitos dos outros. De acordo com Dahl (1992), na visão clássica de virtudes cívicas: "O bom cidadão é altamente preocupado com assuntos públicos e com a vida política; bem informado sobre as questões, os candidatos e os partidos; frequentemente engajado com concidadãos nas deliberações sobre questões públicas; participante ativo nos esforços para influenciar as decisóes governamentais votando, comunicando o seu ponto de vista aos políticos eleitos, participando de reuniōes políticas e similares, sendo motivado, em todas essas atividades, por um desejo de promover o bem-estar geral" (Idem, p. 47). Para o autor, mesmo se considerarmos uma visão mais estreita, vinculada ao individualismo liberal, poucos são os cidadãos interessados e envolvidos profundamente na política. Pelo menos três elementos são limitadores nas sociedades atuais: as mudanças nas escalas da vida pública; um aumento na complexidade dos problemas e das políticas públicas; as mudanças tecnológicas. Tendo essas dificuldades em mente, Warren (2001) assume uma perspectiva mais prudente, seguindo análise de Cohen e Rogers (1995) que apresenta um conjunto mais discreto de efeitos, como forjar uma base de consciência cívica por meio do reconhecimento das normas básicas dos processos democráticos para o argumento político e a cooperação social.

17 De acordo com Warren (2001, p. 81), esse tipo de atuação política é diferente da atuação deliberativa, pois requer o reconhecimento recíproco dos falantes via troca de argumentos, informações, representações, responsabilidades e igualdade. Em condiçõos de poder e dinheiro, há que se ressaltar a importância dos públicos subalternos, especializados na construção de contra-hegemonias (cf. Fraser, 1992). 
18 Ou seja, ser uma forma de organização livre com alto potencial de saída, o que se aproximaria mais da ideia de associação secundária. Nas associações voluntárias, as relações associativas são dominantes e os conflitos internos tendem a ser mais limitados, seja em função da facilidade da saída como meio menos custoso em situaçōes de conflito, seja pelo forte caráter identitário dado pelos processos de autosseleção que tendem a favorecer um grupo mais homogêneo. Nesses casos, os conflitos internos são mais raros, já que potencializam a ameaça da solidariedade e da missão da associação (Warren, 2001, p. 98). Nas associações não voluntárias, caracterizadas pela dificuldade ou maior custo de saída, como são os sindicatos ou as associações profissionais, os conflitos internos se colocam de forma mais clara, embora a diversidade de posturas, interesses e opiniōes revele maior dificuldade de construção de uma identidade como motor de uma atuação pública combativa.

19 Um exemplo interessante é o estudo de Baggetta (2009) sobre os grupos de corais nos Estados Unidos. Mesmo sendo grupos com objetivos bem específicos e distantes de estarem voltados para a criação de oportunidades cívicas, eles apresentam importante potencial nesse sentido, ao promoverem interação, experiência gerencial e conexão com outras instituições.

\section{BIBLIOGRAFIA}

ABERS, R. \& BULOW, M (2011), "Movimentos sociais na teoria e na prática: como estudar o ativismo através da fronteira entre estado e sociedade?". Sociologias, 13 (28): 52-84.

ALEXANDER, J (1998), "Ação coletiva, cultura e sociedade civil: secularização, atualização, inversão, revisão e deslocamento do modelo clássico dos movimentos sociais". Revista Brasileira de Ciências Sociais, 13 (37): 5-31.

ALMOND, G. \& VERBA, S (1963), The civic culture. Princeton, NJ, Princeton University Press.

ALONSO, A (2009), "As teorias dos movimentos sociais: um balanço do debate". Lua Nova, 76: 49-86.

ARATO, A \& COHEN, J. (1992), "Civil society and political theory”. Cambridge, MA, MIT Press. (1994), Sociedade civil e teoria social, in L. Avritzer (org.), Sociedade civil e democratização, Belo Horizonte, Del Rey.
AVRITZER, L (1997), "Um desenho institucional para o novo associativismo". Lua Nova, 39: 149-174.

AVRITZER, L. (2007), "Sociedade civil, instituições participativas e representação: da autorização à legitimidade da ação”. Dados, 50, (3): 443-464.

BAGGETTA, M (2009), "Civic opportunities in associations: interpersonal interaction, governance experience and institutional relationships". Social Forces, 88 (1): 175-199.

BEAUDOIN, C. E (2011), "News effects on bonding and bridging social capital: an empirical study relevant to ethnicity in the United States". Communication Research, 38 (2): 155-178.

BEALL, J (1997), "Social capital in waste: a solid investment?”. Journal of International Development, 9 (7): 951-961.

BRYCESON, D. F (2000), "Disappearing peasantries? Rural labour redundancy in the neo-liberal era and beyond", in D. F. Bryceson, C. Kay e J. Mooij (orgs.), Disappearing peasantries? Rural labour in Africa, Asia and Latin America, Londres, Intermediate Technology Publications.

CHAMBERS, S. \& KOPSTEIN, J (2001), “Bad civil society”. Political Theory, 29 (6): 837-865. (2006), "Civil society and the State", in J. Dryzek, B. Honig e A. Phillips (orgs.), The Oxford handbook of political theory, Oxford, Oxford University Press.

COHEN, J (1999), "Deliberation and democratic legitimacy”, in J. Bohman e W. Regh (orgs.), Deliberative democracy. essays on reason and politics, Cambridge, MA, MIT Press.

COHEN, J. \& ROGERS, J (1995), Associations and democracy. Londres, Verso.

COSTA, S. (1997), "Categoria analítica ou passe-partout político-normativo: notas bibliográficas sobre o conceito de sociedade civil”. Revista Brasileira de Informação Bibliográfica em Ciências Sociais, 43, 1997.

DAGNINO, E.; OLVERA, A. J. \& PANFICHI, A (2006), "Para uma outra leitura da disputa pela construção democrática na América Latina”, in (orgs), A disputa pela construção democrática na América Latina, São Paulo/Campinas, Paz e Terra/Editora da Unicamp, 2006. 
DAHL, R (1992), "The problem of civic competence". Journal of Democracy, 3 (4): 45-59.

DELLA PORTA, D. (2005), "Deliberation in movement: why and how to study deliberative democracy and social movements". Acta Politica, 40 (3): 336-350.

DIANI, M. \& BISON, I (2010), "Organizações, coalizôes e movimentos", Revista Brasileira de Ciência Política, 3: 220-249.

ELSTUB, S (2007), "Overcoming complexity: institutionalising deliberative democracy through secondary associations". The Good Society, 16 (1): 14-22.

ELSTUB, S (2008), Towards a deliberative and associational democracy. Edimburgo, Edinburg

University Press.

FRASER, N (1992), "Rethinking the public sphere", in C. Calhoum (org.), Habermas and the public sphere, Cambridge, MA, MIT Press.

FUNG, A (2003), "Associations and democracy: between theories, hopes, and realities". Annual Review of Sociology, 29: 515-539.

GOLDSTONE, J (org) (2003), States, parties and social movements. Cambridge, Cambridge University Press.

GALSTON, W. A (2000), "Civil society and the 'art of association'”. Journal of Democracy, 11 (1): 64-70.

GURZA LAVALLE, A. (1999), "Crítica ao modelo da nova sociedade civil”. Lua Nova, 47: 121-135. (2003), "Sem pena nem glória: o debate da sociedade civil nos anos 1990". Novos Estudos, 66: 91-110.

GURZA LAVALLE, A.; ISUNZA VERA, E. (2011), A trama da crítica democrática: da participação à representação e à accountability. Lua Nova, 84: 95-139.

HABERMAS, J (1987), Teoria de la acción comunicativa. Madri, Taurus.

(1990), Para a reconstrução do materialismo histórico. São Paulo, Brasiliense.

(1997), Direito e democracia: entre facticidade e validade. Rio Janeiro, Tempo Brasileiro, vol 2.

HERREROS, F (2000), "Social capital, associations and civic republicanism", in M. Saward (org.), Democratic innovation: deliberation, representation and association. Londres/Nova York, Routledge.

HIGGINS, S. S. S (2005), Fundamentos teóricos do capital social. Chapecó, SC, Argos Editora Universitária.

HIRST, p (1994), Associative democracy: new forms of economic and social governance. Amherst, MA, University of Massachusetts Press.

(2001), "Can associationalism come back?”, in P. Hirst e V. Bader (orgs.), Associative democracy: the real third way. Londres, F. Cass.

HOUTZAGER, p.; LAVALLE, A. G. \&ACHARYA, A (2004), "Atores da sociedade civil e atores políticos: participação nas novas políticas democráticas em São Paulo", in L. Avritzer (org.), A participação em São Paulo, São Paulo, Editora da Unesp.

KERSTENETZKY, C. L (2003), "Sobre associativismo, desigualdades e democracia". Revista Brasileira de Ciências Sociais, 18 (53): 131-152.

LÜCHMANN, L. H. H (2011), "Associaçôes, participação e representação: combinações e tensões". Lua Nova, 84: 141-174.

(2012), "Modelos contemporâneos de democracia e o papel das associaçōes". Revista de Sociologia e Politica, 20 (43): 59-80.

MCADAM, D.; McCARTHY, J. D. \& ZALD, M. N (2008), "Opportunities, mobilizing structures, and framing processes: toward a synthetic, comparative perspective on social movements" (introdução), in Comparative perspectives on social movements. Nova York, Cambridge University Press.

MELUCCI, A (2001), A invenção do presente: movimentos sociais nas sociedades complexas. Petrópolis, Vozes.

MEYER, D. S (2004), "Protest and political opportunities". Annual Review of Sociology, 30: 125-145.

PAXTON, p (2002), "Social capital and democracy: an interdependent relationship". American Sociological Review, 67 (2): 254-277.

PERUZZOTTI, E (2006), "Civil society, representation and accountability: restating current debates on the representativeness and accountability of civic associations", in L. Jordan e P. 
van Tuijl (orgs.), NGO accountability: politics, principles and innovations, Londres, Earthscan. (2008), Representative democracy as mediated politics: rethinking the links between representation and participation. Londres, London School of Economics. Disponível em www. academia.edu/4988214/Representative_Democracy_as_Mediated_Politics_Rethinking the_Links_between_Participation_and_Representation>, consultado em 2/6/2014.

PUTNAM, R (1995), “Bowling alone: America's declining social capital”. Journal of Democracy, 6, (1): 65-78.

(1996), Comunidade e democracia: a experiência da Itália moderna. Rio de Janeiro, FGV.

PUTZEL, J (1997), “Accounting for the 'dark side' of social capital: reading Robert Putnam on democracy". Journal of International Development, 9 (7): 939-949.

RENNÓ, L. R (2003), "Estruturas de oportunidade política e engajamento em organizações da sociedade civil: um estudo comparado sobre a América Latina". Revista de Sociologia e Politica, 21: 71-82.

ROBTEUTSCHER, S (2005), Democracy and the role of associations. Londres/Nova York, Routledge.

SCHERER-WARREN, I (2006), "Das mobilizaçôes às redes de movimentos sociais”. Sociedade e Estado, 21 (1): 109-130.

SCHNEIBERG, M. \& LOUNSBURY, M (2008), "Social movements and institutional analysis", in R. Greenwood, C. Oliver, K. Sahlin-Andersson e R. Suddaby (orgs.), The handbook of organizational institutionalism. London, Sage.

SILVA, M. K (2006), "Sociedade civil e construção democrática: do maniqueísmo essencialista à abordagem relacional". Sociologias, 8 (16): 156-179.

SKOCPOL, T (2003), Diminished democracy: from membership to management in American civic life. Norman, OK, University of Oklahoma Press.

STOLLE, D. \& THOMAS R. R (1998), Are all associations alike? Member diversity, associational type, and the creation of social capital". American Behavioral Scientist, 42 (1): 47-65.
SZASZ, A (1995), "Progress through mischief: the social movement alternative to secundary associations", em J. Cohen e J. Rogers, J (orgs.), Associations and democracy, Londres, Verso.

TARROW, S (1999), Power in movement: social movements and contentious politics. Cambridge, Cambridge University Press.

TILLY, C (2006), Regimes and repertoiries. Chicago, University of Chicago Press.

TOCQUEVILlE, A. de (1987), A democracia na America. 3. ed. Belo Horizonte, Itatiaia.

URBINATI, N. \& WARREN, M (2008), "The concept of representation in contemporary democratic theory". Annual Review of Political Science, 11: 387-412.

VERBA, S. \& NIE, N (1972), Participation in America: political democracy and social equality. Nova York, Harper \& Row.

WARREN, M (2001), Democracy and association. Princeton, NJ, Princeton University Press. 


\section{ABORDAGENS TEÓRICAS SOBRE O ASSOCIATIVISMO E SEUS EFEITOS DEMOCRÁTICOS}

\section{Lígia Helena Hahn Lüchmann}

Palavras-chave: Associação; Democracia; Sociedade civil; Movimentos sociais; $\mathrm{Ca}-$ pital social.

Tendo em vista contribuir nos estudos que visam capturar a pluralidade do fenômeno do associativismo, o trabalho pretende recuperar elementos de alguns dos principais aportes teóricos que, de formas variadas, colocam a "arte da associação" como elemento central para se pensar processos de democratização das sociedades, com destaque para três perspectivas analíticas que revelam, cada qual, determinadas características democráticas das associações, quais sejam: capital social, movimentos sociais e sociedade civil. Dialogando com a análise de Warren (2001) acerca da "ecologia democrática das associações”, o trabalho aponta para os ganhos, embora algumas inconsistências, da combinação e da incorporação dos pressupostos dessas diferentes vertentes tendo em vista lidar com a pluralidade e a complexidade do campo associativo nas sociedades contemporâneas.

\section{THEORETICAL APPROACHES ON ASSOCIATION AND ITS DEMOCRATIC EFFECTS}

\section{Lígia Helena Hahn Lüchmann}

Keywords: Association; Democracy; Civil society; Social movements; Social capital.

In order to contribute to studies aiming at capturing the diversity of the phenomenon of association, this article seeks to reclaim some of the main theoretical contributions that, in varied forms, put the "art of association" as a central element for thinking about processes of democratization of societies. Emphasis is given to three analytical perspectives that reveal certain features of democratic associations, represented by the concepts of social capital, social movements, and civil society. In dialogue with the analysis of Warren (2001) about the 'democratic ecology of associations', the work suggests the gains that, despite some inconsistencies, would result from the combination and incorporation of these different positions in dealing with the diversity and complexity of the associative field in contemporary societies.

\section{ABORDAGES THÉORIQUES SUR L'ASSOCIATION ET SES EFFETS DÉMOCRATIQUES}

\section{Lígia Helena Hahn Lüchmann}

Mots-clés: Association; Démocratie; Société civile; Mouvements sociaux; Capital social.

En vue de contribuer aux études qui ont pour but de capturer la pluralité du phénomène de l'association, ce travail propose de récupérer des éléments de certains des principaux apports théoriques qui, de façons diverses, placent " lart de lassociation" en tant quélément central pour penser les processus de démocratisation des sociétés. Il met en avant trois perspectives analytiques qui révèlent, chacune dientre elles, certaines caractéristiques démocratiques des associations, crest-à-dire: le capital social, les mouvements sociaux et la société civile. Tout en dialoguant avec lranalyse de Warren (2001) à propos de "l’écologie démocratique des associations ", le travail indique, malgré certaines inconsistances, des gains de combinaison et dincorporation des présupposés de ces différents points de vue, tout en travaillant avec la pluralité et la complexité du domaine associatif des société contemporaines. 